ks. Jan Żelazny

\title{
Pedagogiczne podejście do odbiorcy. Rozważania w oparciu o Homilie św. Jana Chryzostoma do Listu do Hebrajczyków
}

„Jak gdyby ktoś chciał małego chłopca wyprowadzić na jakieś miejsce wysokie i sięgające szczytów nieba, czyni to powoli, po trochu, prowadząc go stopniowo z dołu, a postawiwszy go potem na górze i kazawszy mu uważnie patrzeć na dół, gdyby [przewodnik] zobaczył, że [chłopiec] dostaje zawrotu głowy, ogarnia go niepokój i ćmi się mu w oczach, chwyta go, sprowadza znowu niżej pozwala odetchnąć, a potem, kiedy przyjdzie do siebie, znowu go prowadzi w górę i znowu sprowadza w dół - tak czynił i błogosławiony Paweł i z Hebrajczykami i wszędzie indziej, nauczywszy się tego od Mistrza"1.

\section{Fascynacja Pawłem}

Dla żadnego z badaczy spuścizny antiocheńczyka nie ulega wątpliwości jego autentyczny zachwyt i zauroczenie postacią Apostoła Narodów. W wielu swoich homiliach, niekoniecznie komentarzach do Listów apostoła, dawał on wyraz swojej fascynacji Pawłem, który był dla niego nie tylko nauczycielem, ale i wzorem postępowania ewangeliczną drogą za Mistrzem z Nazaretu. O takiej postawie św. Jana Chryzostoma świadczy nie tylko cały cykl kazań - homilii i jednego komentarza do Corpus Paulinum, ale przede wszystkim cykl homilii o św. Pawle ${ }^{2}$. Są to laudacje, ale jednocześnie są to te spośród zachowanych jego wystąpien, które ukazują osobisty stosunek antiocheńczyka do Apostola Narodów. Paweł, będąc dla Jana mistrzem życia duchowego, był, jego zdaniem, przykładem zachowania i postępowania dla każdego chrześcijanina niezależnie od specyfiki osobistego powołania. Jak sam pisał, „czy to bowiem prorocy pokazali coś wybornego, czy patriarcho-

${ }^{1}$ Homilie św. Jana Chryzostoma do Listu do Hebrajczyków I, 2.

${ }^{2}$ De laudibus sancti Pauli apostoli. Homilia I, [w:] S. P. N. Joannis Chrysostomi, archiepiscopi Constantinopolotani, opera omnia quae exstant..., accurante et denuo recognoscente J.-P. Migne, t. 2, cz. 2, Lutetiae Parisorum 1862, k. 473n (Patrologiae Cursus Completus. Series Graeca, 50). 
wie, czy sprawiedliwi, czy apostołowie, czy męczennicy, to wszystko razem zebrawszy, Paweł posiadał w takim nadmiarze, w jakim nikt $\mathrm{z}$ owych nie miał jednej cnoty sobie właściwej”’. Zresztą, zdaniem Chryzostoma, kiedy Paweł „był na ziemi i otoczony jeszcze śmiertelnym ciałem, współzawodniczył z mocami bezcielesnymi”4, dlatego mógł być porównywany z aniołami. Doskonałość Apostoła Narodów dotyczyła nie tylko wytrwałości w głoszeniu Ewangelii czy mądrości, ale także relacji do innych ludzi, stosunku do ubogich, postawy względem rządzących etc. Apostoł Narodów jest przykładem życia dla każdego z wiernych, bez względu na stan, charakter pracy czy wiek. Często w swoich kazaniach ten rys jego postaci - wzoru do naśladowania w codziennych wydarzeniach życia - próbował św. Jan Chryzostom przybliżyć wiernym. Na podstawie różnych wypowiedzi czy pojedynczych decyzji starał się ustalić ogólne reguły czy zasady postępowania. Czasem wnioski te były dość ogólne, wiele stwierdzeń miało charakter, dla dzisiejszego egzegety, nieuprawniony, daleki od sensu dosłownego, historycznego, często reguły podawane jako zalecenia apostoła były poza zamierzeniami samego autora natchnionego. Ale zawsze było to podyktowane troską patriarchy, by ukazać wiernym praktyczny zestaw reguł, które pozwoliłyby pójść za Chrystusem i jak św. Paweł stać się Jego apostołem w życiu i postępowaniu. Postać Apostoła Narodów była dla antiocheńczyka drogowskazem na drodze za Zbawicielem, jasnym punktem orientacyjnym, a nie celem drogi. Stąd też wola uogólniania pewnych wniosków, tworzenia reguł. Celem pierwszorzędnym było odkrycie zasad ewangelicznych, które obowiązują św. Pawła, Jana Chryzostoma, każdego z wiernych. Zadaniem wspólnym dla wszystkich chrześcijan jest pójście tą drogą za Chrystusem.

\section{Pawłowe autorstwo Listu do Hebrajczyków}

Antiocheńczyk uważał Corpus Paulinum za zbiór 14 listów Apostoła Narodów będących dziełem samego Pawła. Wychowany w środowisku antiocheńskim, wyczulony na krytyczno-historyczny aspekt egzegezy, pomimo różnego typu dyskusji włączał do Corpus Paulinum także List do Hebrajczyków. Jednak głęboka znajomość języka greckiego nie pozwalała mu nie dostrzegać różnic w każdym z nich. Nie tylko kwestie filologiczne musiały budzić wątpliwości tego uważnego czytelnika apostola Pawła, a takim był przecież wychowanek Diodora z Tarsu. W opisach nawrócenia podanych w Dziejach Apostolskich oraz w Listach pojawiają się różnice:

${ }^{3}$ De laudibus sancti Pauli apostoli. Homilia I, 1, [w:] S. P. N. Joannis Chrysostomi, archiepiscopi Constantinopolotani, opera omnia..., dz. cyt., t. 2, cz. 2, k. 473. Tekst polski na podstawie tłumaczenia T. Sinki: św. Jan Złotousty, Dwadzieścia Homilij i mów, Kraków 1947, s. 212-213.

${ }^{4}$ Tamże, 5. Tekst polski: św. Jan Złotousty, Dwadzieścia ..., dz. cyt., s. 219. 
inaczej w Liście do Hebrajczyków definiuje św. Paweł swoje zadania apostolskie, inny jest sposób argumentacji, poruszane zagadnienia, używane terminy, wreszcie postawa względem adresatów. W ramach jednego listu pojawiają się różne partie, zmienia się ton wypowiedzi apostolskich. Św. Jan Chryzostom żył Pismem Świętym, Ewangelią, te wszystkie sprawy były dla niego czytelne. Tym niemniej traktował wszystkie Listy jako dzieło jednego autora, a jego wysiłek był zwrócony na harmonizację i wyjaśnienie różnic, a nie na kwestię ustalenia autorstwa. Jego zadaniem było podprowadzenie do lektury wiernych, których spotkał przed amboną, zarówno tych wykształconych, jak i prostych ludzi.

Św. Jan Chryzostom nie próbował nie dostrzegać sprzeczności czy trudnych zagadnień. Stąd przy lekturze Listu do Hebrajczyków jedna kwestia, zdaniem Złotoustego, od razu na wstępie budziła nieufność. Dlaczego ten, który ogłaszał całemu światu, że jest apostołem pogan, zwraca się teraz bezpośrednio do Żydów? Chryzostom zauważa, że z punktu widzenia postronnego obserwatora wychowanek Gamaliela świetnie znający Prawo był wprost predestynowany, by stać się apostołem wśród swoich rodaków. Jednak, jego zdaniem, właśnie to rodziłoby najwięcej sprzeciwów. Pisał: ,jeżeli ktoś odstąpi od jakiegoś ludu, to jeśliby był z najniższych warstw i nikt z nim by się nie liczył, nie bardzo to martwi tych, od których się odsuną;; gdy jest to ktoś z ludzi podziwianych, bardzo gorliwych i podzielających przekonania, sprawia bardzo wielką boleść i zasmuca"5. Ale to sprawiałoby mu trudność w nauczaniu tych Żydów, którzy nie przyjęli nauki Chrystusa. Tymczasem Dzieje Apostolskie i Listy ukazują sprzeciw wobec jego nauczania nawróconych Hebrajczyków. Zdaniem Jana, apostołowie głosząc Chrystusa w Jerozolimie, zachowywali Prawo, Paweł niosąc Dobrą Nowinę poganom zrezygnował z Prawa i to rodziło napięcia. Dlatego Pan określił jego zadanie w inny sposób i skierował go do pogan. Tłumaczenie podane przez antiocheńczyka jest dość słabe - św. Paweł podjął działalność apostolską wśród pogan na marginesie swojej posługi, innymi słowy czynił to „ubocznie”: „tak, jak nie otrzymał polecenia, by chrzcił, a chrzcił (nie posłał mnie Chrystus, abym chrzcił - 1 Kor 1, 17), jednak nie miał zakazu, lecz czynił to ubocznie" . Jednakże, zdaniem Chryzostoma, to zwrócenie uwagi przez Apostoła Narodów na naród ojczysty nie powinno dziwić. Listy Pawła są pełne wyrazów jego troski o Izrael. Kochał swój naród, stąd pod koniec życia zwraca się także do rodaków mieszkających w Judei. Jeżeli pamięta się o jego zaangażowaniu w pomoc charytatywną mieszkańcom Judei, jeżeli pamięta się jego wezwania w Listach mówiące o wielkiej miłości, jaką darzył

${ }^{5}$ Homilie św. Jana Chryzostoma do Listu do Hebrajczyków, prolog, 1.

${ }^{6}$ Tamże. 
współbraci Hebrajczyków, nie powinno to dziwić. Wręcz przeciwnie, zdaniem Złotoustego, wpisuje się to w logikę działania Apostoła Narodów.

Samo powstanie Listu do Hebrajczyków przesuwa nasz kaznodzieja na okres po wypuszczeniu Pawła pierwszy raz z więzienia w Rzymie i po jego hipotetycznej podróży do Hiszpanii. Stąd, jego zdaniem, jest on wcześniejszy od Listu do Tymoteusza, który został napisany podczas powtórnego pobytu w Rzymie, tuż przed męczeńską śmiercią apostoła7.

Św. Jan nie tylko dostrzegał te oraz inne sporne kwestie, on w jasny sposób mówił słuchaczom o nich i o innych zastrzeżeniach. Zwracając uwage na pozorne pominięcia, powtórzenia czy też - na pierwszy rzut oka - niekonsekwencje w postępowaniu Pawła, chciał pobudzić słuchaczy do uwagi, zaciekawić ich, zmusić do refleksji. Zagadnienia te musiały budzić pytania. Jeżeli o nich wspominał, to po to, by na końcu udzielić słuchaczom wystarczającej odpowiedzi. Wyjaśnienia ukazywały praktyczną mądrość Apostoła Narodów. Kluczem egzegezy Jana Chryzostoma była doskonała znajomość Pisma i zdolność do harmonizacji kolejnych epizodów czy wypowiedzi.

Biskup Konstantynopola miał jednak kilka założeń, które ułatwiały mu takie postępowanie. Jednym z nich - podstawowym - było przeświadczenie, że w całej działalności św. Pawła mamy do czynienia z pedagogią, która nakazuje dostosować przekaz do możliwości odbioru przez słuchaczy, ich zaangażowania, a także tego, w jaki sposób postrzegali samego Pawła. To właśnie wzglą na osobę kazał, zdaniem św. Jana Chryzostoma, dostosowywać Apostołowi Narodów sposób przekazu. Komunikatywność wymuszałaby konkretne zachowania, sformułowania, narzucałaby tematy i ich rozpracowanie. Metoda ta nie zmienia nic w samym przekazie, ale powoduje, że jest on tak skonstruowany, by jak najpełniej mógł dotrzeć do słuchaczy.

Za przykład niech posłużą nam dwie Homilie, Prolog i Homilia I będące wstępem do całego cyklu kazań do Listu do Hebrajczyków.

\section{Pedagogiczny aspekt różnic w opisach i stylu}

„Jak gdyby ktoś chciał małego chłopca wyprowadzić na jakieś miejsce wysokie i sięgające szczytów nieba, czyni to powoli, po trochu, prowadząc go stopniowo z dołu, a postawiwszy go potem na górze i kazawszy mu uważnie patrzeć na dół, gdyby [przewodnik] zobaczył, że [chłopiec] dostaje zawrotu głowy, ogarnia go niepokój i ćmi się mu w oczach, chwyta go, sprowadza znowu niżej pozwala odetchnąć, a potem, kiedy przyjdzie do siebie, znowu go

${ }^{7}$ Tamże. 
prowadzi w górę i znowu sprowadza w dół - tak czynił i błogosławiony Paweł i z Hebrajczykami i wszędzie indziej, nauczywszy się tego od Mistrza".

Św. Jan Chryzostom porównuje postępowanie św. Pawła Apostoła do zachowania przewodnika w górach. Ma on przeprowadzić przez górskie szczyty kogoś, kto z uwagi na wiek czy własne doświadczenie nie czuje się pewnie na szlaku. Sama droga też nie jest ani łatwa, ani bezpieczna. Przewodnik więc oswaja prowadzonego z krajobrazem i niebezpieczeństwami. Dlatego raz wprowadza wzwyż, raz zajmuje uwagę horyzontem, innym razem uczula na niebezpieczeństwa. Jego rady są raz ostrzeżeniem, innym razem zachętą. Za każdym razem jednak mają na celu dobro prowadzonego i są relacją między mistrzem a uczniem.

Taka postawa tłumaczy, zdaniem Jan Chryzostoma, większość nieciągłości, z jakimi spotykamy się w Liście do Hebrajczyków, jak i styl Listu. Paweł pisze do Żydów, ludzi, którzy otrzymali poznanie Boga przez proroków, przez interwencje samego Stwórcy. Nie może więc Apostoł Narodów, zwracając się do nich, pisać jako ktoś posiadający autorytet. Są ku temu trzy argumenty: „po pierwsze dlatego, że wzbrania się mówić o sobie wielkie rzeczy; po drugie dlatego, że słuchacze nie są jeszcze doskonali; po trzecie chcąc ich bardziej podnieść i wskazać ich znaczną wyższość" ". Musi dowodzić, odwoływać się do autorytetu swoich poprzedników, obrazować nauczanie odniesieniem do liturgii świątynnej. Paweł, zdaniem antiocheńczyka, ma świadomość, że dla Hebrajczyków wybór Boga był źródłem dumy, a interwencje w historii stanowiły źródło poczucia własnej godności. Ukazując misję Chrystusa, opiera się z jednej strony na fundamencie zapowiedzi i obrazów Starego Przymierza, $z$ drugiej wprowadza słuchaczy na inny poziom, ukazując im nowe przestrzenie, nowe horyzonty, do jakich prowadzi ich Stwórca, objawiając się w tych czasach już nie przez proroków czy aniołów-współniewolników, ale poprzez samego Jednorodzonego Syna. Apostoł chce zachęcić ich, pragnie ukazać „współrodakom, że otrzymali większą i daleko wyższą łaskę"10.

Prześledźmy dalej w tym kluczu myśl Pawła w pierwszych wersach Listu do Hebrajczyków, podążając szlakiem wyznaczonym przez Jana Chryzostoma. Apostoł Narodów, zdaniem kaznodziei, by nie wystraszyć odbiorców, nie używa sformułowania, które spotykamy w innych Listach, typu „Chrystus rzekł” czy też „mówię wam”, z powołaniem się na własną godność apostolską. Paweł wypowiada się na samym początku: „przemówił do nas przez Syna”11. Nie używa autorytetu, stawia się razem ze słuchaczami w jednym szeregu

\footnotetext{
${ }^{8}$ Homilie św. Jana Chryzostoma do Listu do Hebrajczyków I, 2.

${ }^{9}$ Homilie św. Jana Chryzostoma do Listu do Hebrajczyków I, 1.

${ }^{10}$ Tamże.

${ }^{11}$ Hbr 1, 1; por. Homilie św. Jana Chryzostoma do Listu do Hebrajczyków I, 1.
} 
jako odbiorca wezwania Boga. Sformułowanie to podkreśla wspólnotę krwi pomiędzy Żydami i Pawłem, odwołuje się do wspólnych więzi. Ustawia adresatów wraz z autorem w tej samej linii jako wezwanych wspólnie do wysłuchania tego, co Bóg poleca ludowi. Takie postawienie zagadnienia wpisywało się w historię zbawienia jako kolejny logiczny krok w objawieniu się Stwórcy stworzeniu i odwoływało się do wspólnego im dziedzictwa religijnego. Nauka Pawła nie przychodziła jako novum, ale jako uzupełnienie, wypełnienie zapowiedzi prorockich. Zarówno w sformułowaniu, jak i w odwołaniu widać tę samą pedagogię Pawła na wzór Mistrza z Nazaretu.

Tym też tłumaczy nasz antiocheńczyk kolejną zmianę tematu i zwrócenie przez apostoła uwagi czytelników na osobę Chrystusa. A było to zagadnienie kluczowe i jednocześnie, w kontekście całej sytuacji religijnopolitycznej w samej stolicy, najbardziej kontrowersyjne. W tłumaczeniu fragmentu odnoszącego się do tajemnicy bóstwa Syna i jedynego tekstu Nowego Testamentu używającego słowa hypostasis $w$ odniesieniu do natury (bytu? substancji?) Syna w powiązaniu z bóstwem Ojcem, widać przytoczoną zasadę w całej pełni, więc pozwólmy sobie zacytować ten tekst w całości: „Patrz więc, przez jakie stopnie ich tu wprowadził w górę i postawił na samym szczycie pobożności, a zanim dostali zawrotu głowy i zaćmienia w oczach, jak ich znowu sprowadza niżej i pozwala im odetchnąć, mówiąc: «Przemówił do nas przez Syna» i znów: «którego ustanowił dziedzicem wszystkiego». Albowiem imię Syna dotychczas jest wspólne. Wszak gdzie rozumie się prawowitego syna, jest on wyższy od wszystkich, na razie zaś, jakkolwiek by było, chwali i okazuje, że jest z nieba.

Patrz, jak dalej stawia na niższym stopniu, mówiąc: «którego ustanowił dziedzicem wszystkiego» gdyż to «ustanowił dziedzicem» jest pojęciem niskim. Potem wprowadza na wyższy stopień: «i przez którego stworzył także wieki», potem na jeszcze wyższy, po którym nie ma innego: «Ten będąc odblaskiem Jego chwały i odbiciem Jego istoty». Rzeczywiście zaprowadził do świata niedostępnego, do samego blasku. I zanim się zaćmi, patrz, jak znowu powoli sprowadza nisko, mówiąc: «I podtrzymując wszystko słowem swej potęgi, sprawiwszy przez siebie oczyszczenie z naszych grzechów, zasiadł po prawicy majestatu». Nie powiedział «zasiadł» lecz «zasiadł po oczyszczeniu», gdy przyjął wcielenie. Tak znowu mówi o niższych rzeczach. Potem głosi coś wzniosłego mówiąc: «Po prawicy majestatu na wysokościach» i znowu się zniża przez dodatek «stawszy się o tyle wyższym od aniołów, o ile odziedziczył wyższe od nich imię». Tu bowiem mówi także o dziele wcielenia, gdyż słowa «stawszym się wyższym» nie wskazują istoty według Ojca, albowiem ta nie stała się, lecz została zrodzona; lecz wskazuje istotę według ciała, ta bowiem stała się"12.

${ }^{12}$ Homilie św. Jana Chryzostoma do Listu do Hebrajczyków I, 2. 
Widać więc, że przytoczona zasada pozwoliła Janowi Chryzostomowi obronić trynitarne znaczenie sformułowania hypostasis/istota $i$ jednocześnie, choć nie wprost, odpowiedzieć milcząco na zarzuty i argumenty arian. Zasada pedagogiczna okazała się użyteczna dogmatycznie, ułatwiając wykład patriarsze Konstantynopola. Ale, należy to podkreślić, obowiązywała ona także w drugim kierunku. Oznaczało to, że fragmenty tekstu, które raczej nie sugerowały odniesień dogmatycznych, mogły stać się okazją do takich dygresji. Komentując słowa: „W każdym położeniu dziękujcie, taka jest bowiem wola Boża w Jezusie Chrystusie względem was. Ducha nie gaście, proroctwa nie lekceważcie” (1 Tm 5, 18-20) nasz autor pisze: „Ścigałem cię i biegłem za tobą, aby cię zatrzymać, zjednoczyłem cię ( sobą"13. Podobne sformułowanie pojawia się w XXIV Homilii do 1 Listu do Koryntian ${ }^{14}$, gdzie odnosząc się do słów: „Ponieważ jeden jest chleb, przeto my, liczni, tworzymy jedno ciało. Wszyscy bowiem bierzemy z tego samego chleba" (1 Kor 10,17), używa w odniesieniu do zjednoczenia w Chrystusie bóstwa i człowieczeństwa tego samego terminu ëvooıs. A są to określenia, których używano w ówczesnej dyskusji na temat związku obu natur w Chrystusie, które były powoli przedmiotem kontrowersji i które wpisywały się w aleksandryjską teologię zstępującą, a nie w charakterystyczną dla środowiska, w którym żył Jan, tzw. wstępującą teologię antiocheńską! Wpisywałoby się to w opisaną wcześniej koncepcję powolnego podprowadzania na szczyt i schodzenia w dół ze słuchaczem, aby z jednej strony przekazać mu naukę, z drugiej nierozważnym poruszeniem zagadnień, do których nie został przygotowany, nie spowodować niepotrzebnego zamieszania ${ }^{15}$.

\section{Interpretacja rozszerzająca - Chryzostomowa zasada pedagogii wobec wiernych}

Ale podobne postępowanie widać w samym odniesieniu św. Jan Chryzostoma do słuchaczy jego homilii. Homilie mają dość łatwy do rozszyfrowania schemat. Po wprowadzeniu mającym za zadanie przybliżyć dany

${ }^{13}$ In Epistolam Primam ad Timotheum Commentarius. Homilia XV, 4, [w:] S. P. N. Joannis Chrysostomi, archiepiscopi Constantinopolotani, opera omnia quae exstant..., dz. cyt., k. 586 (Patrologiae Cursus Completus. Series Graeca, 62).

${ }^{14}$ Argumentum Epistolae Primae ad Corinthios. Homilia XXIV, 2 [w:] S. P. N. Joannis Chrysostomi, archiepiscopi Constantinopolotani, opera omnia quae exstant..., dz. cyt., k. 201 (Patrologiae Cursus Completus. Series Graeca, 61).

${ }^{15}$ Warto też podkreślić, że okazją do wypowiedzenia tak mocnych słów była dygresja dotycząca Eucharystii. Najświętszy sakrament i uczestnictwo w nim jest dla Chryzostoma szczytem wiary, znakiem powołania i zapowiedzią wywyższenia człowieka, a nauka o tej tajemnicy i stosunek do niej staje się dla antiocheńczyka sprawdzianem prawdziwości nauczania i życia religijnego. 
tekst słuchaczom i podać najważniejsze informacje konieczne do jego zrozumienia patriarcha przechodzi do wyjaśnienia - pouczenia przekazującego naukę w sposób prosty, odnoszący ją do zagadnień będących już rozstrzygniętymi. To miejsce nie jest okazją do poruszania spraw spornych. Ta część homilii ma wprowadzić w refleksję, a nie prowokować dyskusję czy kontrowersję. Istotą jest praxis życia, a theoria ma ukazać, jak do niej dojść. Praktyczny, funkcjonalny aspekt teologii Jana Chryzostoma jest widoczny także w formie pouczenia - wyjaśnienia. Następuje to bez odwoływania się do skomplikowanych teorii, obcych i trudnych słów czy też przykładów dalekich od życia większości słuchaczy.

Po takim pouczeniu zaczyna się zachęta moralna, opis piękna powołania. Mówiąc językiem porównania, jak w pierwszym etapie było podprowadzenie na szczyt, tak teraz ukazujemy panoramę. Gdyby jednak ktoś się wystraszył, przechodzimy do dziękczynienia, ukazujemy moc wiary, czyli innymi słowy, sprowadzamy w dół. Po chwili, gdy słuchacz już nieco ochłonął, kaznodzieja podejmuje wysiłek wprowadzenia znów na szczyty. To miejsce jest okazją do wielu dygresji, które często sięgają bardzo głęboko i odważnie podejmują zagadnienia trudne. Skoro raz kaznodzieja wprowadził odbiorcę na szlak, podąża $\mathrm{z}$ nim dalej tą samą drogą, zwracając uwagę na wnioski płynące z nauki, na praxis życia chrześcijańskiego. Tu zawsze dotyka trudnego tematu - przejścia od deklaracji do czynów, do miłosierdzia, filantropii, umiłowania człowieka. Stąd ta część homilii jest na przemian zachętą, upomnieniem, dziękczynieniem. W języku użytego porównania nieustannym wchodzeniem na szczyt, schodzeniem na chwilę w dół i powrotem na te same wysokości. Cała homilia stara się dotrzeć do każdego ze słuchaczy, każdemu pozwala odnaleźć swoje miejsce w Bożym planie zbawienia. Stąd napomnienia rzadko dotyczą jednej grupy wiernych, raczej ukazują, że te same wezwania mogą wypełnić wszyscy, choć każdy w inny sposób, zależny od swojego stanu i możliwości.

\section{Wnioski}

Jakie stąd płyną wnioski? Moim zdaniem można wyróżnić cztery podstawowe, które można podzielić na dwie grupy: dotyczące samej spuścizny Złotoustego jak i ogólnie, przepowiadania Ewangelii.

Do pierwszej grupy należy zaliczyć spostrzeżenie, że jeśli św. Paweł jest dla antiocheńczyka wzorem we wszystkim, to zasady pedagogiczne Apostoła Narodów były praktykowane przez samego Chryzostoma. A to z kolei suponuje, że „pedagogiczny wzgląd na odbiorców” jest jednym z wyznaczników twórczości homiletycznej patriarchy Konstantynopola. Tym można tłumaczyć oszczędne wchodzenie z dogmatyką na ambonę, 
to także tłumaczy, dlaczego teksty kontrowersyjne wcale nie były okazją dla kaznodziei do podjęcia zagadnień trynitarnych czy eklezjologicznych. Wręcz odwrotnie, komentarze w tych miejscach są skrótowe, ograniczają się do tego, co oczywiste, jak gdyby autor chciał uniknąć niepotrzebnych, jego zdaniem, dyskusji. Rodzi to kolejne pytanie, czy zasada ta oznacza nieobecność niektórych zagadnień w jego twórczości? Wniosek brzmi: nie, bo przewodnik św. Jan Chryzostom sprowadza słuchaczy w dół nie po to, by zakryć na zawsze przed nimi panoramę gór, ale po to, by przy innej okazji tych samych słuchaczy, tym razem mniej skłonnych do ucieczki w rozważania filozoficzne, poprowadzić ponownie w kierunku Tajemnicy.

Kolejne zagadnie to spostrzeżenie, że w wielu miejscach właśnie pedagogią Boga będzie thumaczył Chryzostom nieścisłości czy też sformułowania nie do końca czytelne w Piśmie Świętym. Nie jest to słabość ludzkiego redaktora czy też niedoskonałość Pisma, ale uwzględnienie odbiorcy.

Inny wniosek dotyczy doboru tematów poruszanych w homiliach. Jeśli pedagogia jest tak istotna, to muszę w przepowiadaniu uwzględnić oczekiwania odbiorcy, a nie teoretyczne schematy. Jeśli ludzie cierpią głód, to mówię o pomocy, a nie o perychorezie Osób Boskich. Temat jest funkcją życia słuchaczy, a kazanie jest dla odbiorcy, musi więc uwzględniać jego potrzeby. Jest problem z judaizantes - powstaną na ten temat homilie, jest pijaństwo - poruszymy tę kwestię w kazaniu, urzędnicy wywyższają się - będę mówił o pokorze. Jest interakcja pomiędzy życiem a przepowiadaniem, ale nie jest to tylko proste spotkanie z duchem czasów. Jest to zawsze pogłębiona spotkaniem z Ewangelią refleksja nad tym, co Bóg w tej konkretnej sytuacji do mnie mówi. Jednocześnie nie oznacza to rezygnacji z własnych planów edukacyjnych. Wierni nie znają Dziejów Apostolskich - poruszę te zagadnienia na ambonie, choć nigdy nie zapomnę o aktualizacji. Ale zawsze sprowadzam w dół, uspokajam, zachęcam, podtrzymuję na duchu, bo moim zadaniem jest pomóc człowiekowi w wypłynięciu na głębię, a nie tylko rozwiązanie doraźnych problemów.

Te dwa ostatnie elementy zmuszają do wyciagnięcia kolejnego wniosku, a raczej postawienia pewnego ogólnego pytania. Dotyczy ono komunikacji pomiędzy przepowiadającym i przepowiadanym, która w tym wypadku musi uwzględniać nie tylko prawdy objawione czy język i mentalność słuchaczy, ale także ich wewnętrzny rozwój, gotowość do przyjęcia nauki, a także problemy, z którymi na co dzień się borykają.

Może właśnie to pedagogiczne wyczucie było jednym z elementów, które złożyły się na wielkość Jana Chryzostoma jako kaznodziei i duszpasterza? 


\section{Słowa kluczowe}

Jan Chryzostom, homilia, Paweł Apostoł, pedagogia, analiza dogmatyczna

\section{Summary}

\section{Pedagogical attitude toward the audience. Reflexions on St. John Chrysostom's Homilies on the Epistle to the Hebrews}

The fascination with St. Paul's activity was one of St. John Chrysostom characteristic features. In the attitude of the Antiochian we can see not only true admiration but also the will to imitate St. Paul as a guiding light of Christian involvement and activity. St. John Chrysostom has often underlined the pedagogical attitude of the Apostle towards the audience in his letters. Such appraisal of the activity of the Apostle of Nations by the Patriarch of Constantinople determined his own pastoral attitude. As a result of this one of the characteristic features of St. John Chrysostom's preaching is the concern for the audience that accompanied the preacher of Antioch in his homiletic activity. Chrysostom was a master of words, a tutor always dedicated to his audience. This helped with his choice of themes, the topics he discussed or the choice of time in which he undertook particular deliberations. So, controversial texts didn't give a chance for an insightful dogmatic analysis, although none of the topics were passed over. In other words he was concerned not only with what he would convey, but also when and how he would reach the topic with the audience. St. John Chrysostom was aware of the perceptual limitations of his audience hence his caution. Such an approach implies great caution in dealing with his works and at the same time explains why on the one hand some allusions in the commentary to particular parts of the Holy Scripture lack, as well as, the fact that all crucial topics have been discussed by the saint of Antioch. An example of this are the homilies to Corpus Paulinum, and especially the analyzed parts from St. John Chrysostom's Homilies to the Epistle to the Hebrews.

\section{Key words}

John Chrysostom, homily, St. Paul Apostle, pedagogical attitude, dogmatic analysis 